\title{
Correction to: Impact of Gambling Supply Reduction During COVID-19 Shutdowns on Gambling Problems and Gambling Behaviour in Australia: A National Longitudinal Study
}

\author{
Nicola Black ${ }^{1}$ (D) Thomas B. Swanton ${ }^{1}$ (D) - Martin T. Burgess ${ }^{1}$ (D) - Sally M. Gainsbury ${ }^{1}$ (i)
}

Published online: 22 September 2021

(c) Springer Science+Business Media, LLC, part of Springer Nature 2021

\section{Correction to: Journal of Gambling Studies https://doi.org/10.1007/s10899-021-10067-6}

The original version of this article unfortunately contained a mistake in Fig. 1 and also, the references listed under the heading "De-identified References" should be moved into the main references section. The correct Fig. 1 and the updated reference section are given below. The original article has been corrected.

\section{References}

Bade, R., Simpson, B. S., Ghetia, M., Nguyen, L., White, J. M., \& Gerber, C. (2021). Changes in alcohol consumption associated with social distancing and self-isolation policies triggered by COVID-19 in South Australia: A wastewater analysis study. Addiction, 116(6), 1600-1605. https://doi.org/10.1111/ add. 15256

Bartley, C. A., \& Bloch, M. H. (2013). Meta-analysis: Pharmacological treatment of pathological gambling. Expert Review of Neurotherapeutics, 13(8), 887-894. https://doi.org/10.1586/14737175.2013.814938

Biddle, N. (2020). Gambling during the COVID-19 pandemic. Australian National University Centre for Social Research and Methods and Centre for Gambling Research. https://csrm.cass.anu.edu.au/sites/ default/files/docs/2020/12/Gambling_during_the_COVID-19_pandemic.pdf

Calado, F., \& Griffiths, M. D. (2016). Problem gambling worldwide: An update and systematic review of empirical research (2000-2015). Journal of Behavioral Addictions, 5(4), 592-613. https://doi.org/10. $1556 / 2006.5 .2016 .073$

The original article can be found online at https://doi.org/10.1007/s10899-021-10067-6.

Nicola Black

nicola.d.black@gmail.com

Thomas B. Swanton

thomas.swanton@sydney.edu.au

Martin T. Burgess

martin.t.burgess@gmail.com

Sally M. Gainsbury

sally.gainsbury@sydney.edu.au

1 Faculty of Science, School of Psychology, Brain \& Mind Centre, Gambling Treatment \& Research

Clinic, The University of Sydney, 94 Mallett Street, Camperdown, NSW 2050, Australia 


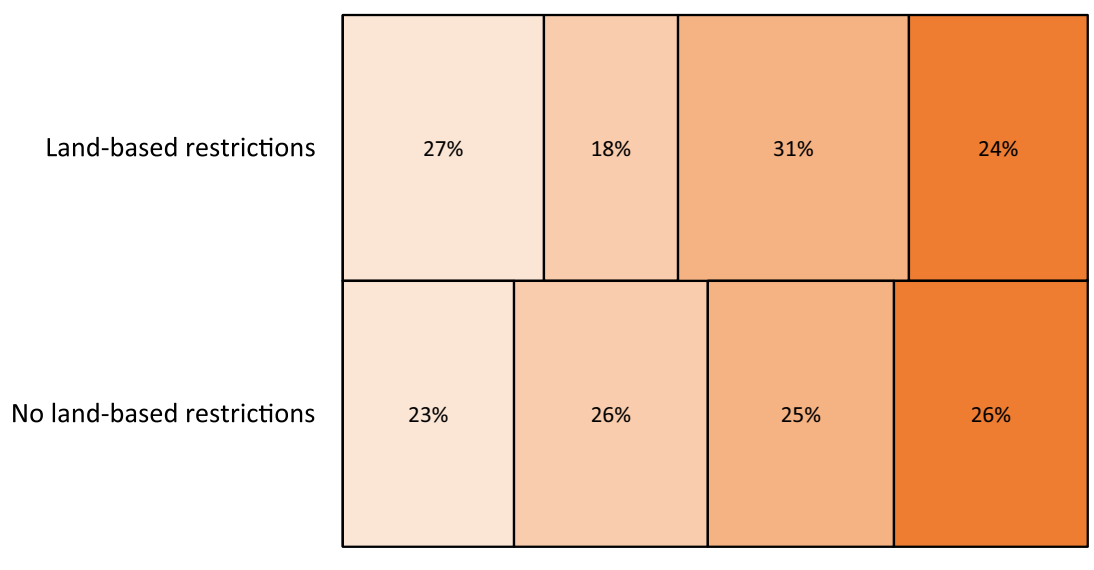

$\square$ No problems $\square$ Low risk $\square$ Moderate risk $\quad \square$ Problem gambling

Fig. 1 Distribution of problem gambling risk status by presence of restrictions to land-based gambling products

Callinan, S., Smit, K., Mojica-Perez, Y., D’Aquino, S., Moore, D., \& Kuntsche, E. (2021). Shifts in alcohol consumption during the COVID-19 pandemic: Early indications from Australia. Addiction, 116(6), 1381-1388. https://doi.org/10.1111/add.15275

Choi, S.-W., Shin, Y.-C., Kim, D.-J., Choi, J.-S., Kim, S., Kim, S.-H., \& Youn, H. (2017). Treatment modalities for patients with gambling disorder. Annals of General Psychiatry, 16, 23. https://doi. org/10.1186/s12991-017-0146-2

Clare, P. J., Aiken, A., Yuen, W. S., Upton, E., Kypri, K., Degenhardt, L., Bruno, R., McCambridge, J., McBride, N., Hutchinson, D., Slade, T., Mattick, R., \& Peacock, A. (2021). Alcohol use among young Australian adults in May-June 2020 during the COVID-19 pandemic: A prospective cohort study. Addiction. https://doi.org/10.1111/add.15599

Dowling, N. A., Merkouris, S. S., Greenwood, C., Oldenhof, E., Toumbourou, J. W., \& Youssef, G. J. (2017). Early risk and protective factors for problem gambling: A systematic review and meta-analysis of longitudinal studies. Clinical Psychology Review, 51, 109-124. https://doi.org/10.1016/j.cpr. 2016.10.008

Ferris, J., \& Wynne, H. (2001). The Canadian problem gambling index: Final report. Canadian Consortium for Gambling Research. https://www.greo.ca/Modules/EvidenceCentre/files/Ferris\%20et\% 20al(2001)The_Canadian_Problem_Gambling_Index.pdf

Gainsbury, S. M., Russell, A., Hing, N., Wood, R., Lubman, D. I., \& Blaszczynski, A. (2014). The prevalence and determinants of problem gambling in Australia: Assessing the impact of interactive gambling and new technologies. Psychology of Addictive Behaviours, 28(3), 769-779. https://doi. org/10.1037/a0036207

Gainsbury, S. M., Swanton, T. B., Burgess, M. T., \& Blaszczynski, A. (2020). Impacts of the COVID-19 shutdown on gambling patterns in Australia: Consideration of problem gambling and psychological distress. Journal of Addiction Medicine. https://doi.org/10.1097/ADM.0000000000000793

Håkansson, A. (2020a). Effects on gambling activity from coronavirus disease 2019_An analysis of revenue-based taxation of online- and land-based gambling operators during the pandemic. Frontiers in Psychiatry, 11, 611939. https://doi.org/10.3389/fpsyt.2020.611939

Håkansson, A. (2020b). Impact of COVID-19 on online gambling-A general population survey during the pandemic. Frontiers in Psychology, 11, 568543. https://doi.org/10.3389/fpsyg.2020.568543

Howe, P. D. L., Vargas-Sáenz, A., Hulbert, C. A., \& Boldero, J. M. (2019). Predictors of gambling and problem gambling in Victoria, Austraila. PLOS ONE, 14, e0209277. https://doi.org/10.1371/journ al.pone.0209277

Kendrick, K., \& Isaac, M. (2020). Mental health impact of COVID-19: Australian perspective. Indian Journal of Psychiatry, 62(Suppl 3), S373-S376. 
Kushnir, V., Godinho, A., Hodgins, D. C., Hendershot, C. S., \& Cunningham, J. A. (2018). Self-directed gambling changes: Trajectory of problem gambling severity in absence of treatment. Journal of Gambling Studies, 34, 1407-1421. https://doi.org/10.1007/s10899-018-9769-8

Lindner, P., Forsström, D., Jonsson, J., Berman, A. H., \& Carlbring, P. (2020). Transitioning between online gambling modalities and decrease in total gambling activities, but no indication of increase in problematic online gambling intensity during the first phase of the COVID-19 outbreak in Sweden: A time series forecast study. Frontiers in Public Health. https://doi.org/10.3389/fpubh.2020.554542

Madley-Dowd, P., Hughes, R., Tilling, K., \& Heron, J. (2019). The proportion of missing data should not be used to guide decisions on multiple imputation. Journal of Clinical Epidemiology, 110, 63-73. https:// doi.org/10.1016/j.jclinepi.2019.02.016

McComb, J. L., \& Sabiston, C. M. (2010). Family influences on adolescent gambling behavior: A review of the literature. Journal of Gambling Studies, 26, 503-520. https://doi.org/10.1007/s10899-010-9181-5

McMahon, N., Thomson, K., Kaner, E., \& Bambra, C. (2019). Effects of prevention and harm reduction interventions on gambling behaviours and gambling related harm: An umbrella review. Addictive Behaviors, 90, 380-388. https://doi.org/10.1016/j.addbeh.2018.11.048

Meyer, G., Kalke, J., \& Hayer, T. (2018). The impact of supply reduction on the prevalence of gambling participation and disordered gambling behavior: A systematic review. Sucht, 64, 283-293. https://doi. org/10.1024/0939-5911/a000562

Ripley, B., Venables, B., Bates, D. M., Hornik, K., Gebhardt, A., \& Firth, D. (2013). Package 'mass'. https://cran.r-project.org/web/packages/MASS/index.html

Slutske, W. S., Piasecki, T. M., Deutsch, A. R., Statham, D. J., \& Martin, N. G. (2019). Potential causal influence of neighborhood disadvantage on disordered gambling: Evidence from a multilevel discordant twin design. Clinical Psychological Science, 7, 582-596.

Storer, J., Abbott, M., \& Stubbs, J. (2009). Access or adaptation? A meta-analysis of surveys of problem gambling prevalence in Australia and New Zealand with respect to concentration of electronic gaming machines. International Gambling Studies, 9, 225-244. https://doi.org/10.1080/14459790903257981

van Buuren, S., \& Groothuis-Oudshoom, K. (2011). mice: Multivariate imputation by chained equations in R. Journal of Statistical Software, 45, 1-67. https://doi.org/10.18637/jss.v045.i03

Welte, J. W., Barnes, G. M., Tidwell, M.-C.O., \& Wieczorek, W. F. (2017). Predictors of problem gambling in the U.S. Journal of Gambling Studies, 33, 327-342. https://doi.org/10.1007/s10899-016-9639-1

White, I. R., Royston, P., \& Wood, A. M. (2011). Multiple imputation using chained equations: Issues and guidance for practice. Statistics in Medicine, 30, 377-399. https://doi.org/10.1002/sim.4067

Wickham, H., Averick, M., Bryan, J., Chang, W., McGowan, L. D., François, R., Grolemund, G., Hayes, A., Henry, L., Hester, J., Kuhn, M., Pedersen, T. L., Miller, E., Bache, S. M., Müller, K., Ooms, J., Robinson, D., Seidel, D. P., Spinu, V., \& Yutani, H. (2019). Welcome to the Tidyverse. Journal of Open Source Software, 4(43), 1686. https://doi.org/10.21105/joss.01686

Publisher's Note Springer Nature remains neutral with regard to jurisdictional claims in published maps and institutional affiliations. 